Article

\title{
Perceived Organizational Support and Career Adaptability as Predictors of Self and Environmental- career Exploration: An Empirical Investigation in China
}

\author{
Yin Ma ${ }^{1}$, Shih-Chih Chen ${ }^{2}$, and Athapol Ruangkanjanases ${ }^{3, *}$ \\ 1 School of Philosophy and Sociology, Lanzhou University, Lanzhou 730030, Gansu, Peoples R China; \\ mayin@lzu.edu.cn \\ 2 Department of Information Management, National Kaohsiung University of Science and Technology, \\ Kaohsiung 824, Taiwan; scchen@nkust.edu.tw \\ 3 Chulalongkorn Business School, Chulalongkorn University, Bangkok 10330, Thailand; \\ athapol@cbs.chula.ac.th \\ * Correspondence: athapol@cbs.chula.ac.th
}

\begin{abstract}
The research aims to examine the extent to which the perceived organizational support (POS) predicted career related self and environmental exploration via the mediation effect of career adaptability. Multi-group comparisons based on the gender, majors and places of origin were also performed to evaluate the differences among these variables. An internet survey was conducted to collect empirical data from 611 Chinese undergraduates. Structural equation modeling (SEM) was conducted to demonstrate the proposed relations in the model and multiple group analysis. Clearly supported was the direct relations between POS and career related self and environmental exploration and the mediation effect of career adaptability. The results also showed that gender and major are the moderating variables for the proposed model, and no significance difference among the rural and urban subgroups was found. POS could be effectively delivered to students in general, marginalized social groups, such as females and those majored in the humanities and social sciences in particular. Four dimensions of career adaptability (concern, control, curiosity and confidence) could also be targeted at in order to promote students' sustainable employment. The findings provide a better understanding of the career construction model by incorporating the contextual factor in a collective cultural environment.
\end{abstract}

Keywords: higher education expansion; sustainable employment; perceived organizational support; career adaptability; self-exploration; environment exploration; sustainable career guidance; sustainability competencies

\section{Background}

The transition from university to workplace is a vital phase for graduates [1, 2]. This process, however, is not easy for them. Without much work-related experience or professional-oriented learning, graduates often encounter difficulties during this transition. The competition has become even stiffer, for the expansion of higher education has led to a large number of job candidates, who cannot be fully absorbed by the labor market. This phenomenon, over-supply of university students, can be observed worldwide [3, 4]. Chinese higher education system also experienced the expansion process [5]. Unlike its western counterparts, China finished its transition from elite higher education period to massified one very quickly: 
"The year 1999 saw an abrupt jump in new enrolments, with 1.59 million new students, up from 1.08 million in the previous year, or an annual increase of $47.2 \%$ !...The participation rate was raised by $15 \%$ in 10 years, from around 9\% in 1998. By contrast, it took the United States 30 years (1911-1941), Japan 23 years (1947-1970), and many European countries 25 years to make the same journey." [5]

The sharp increase in the university enrollment rates has inevitably resulted in the difficulty for graduates seeking jobs [4, 6], which poses great challenges to the sustainable development of higher education systems and social justices systems [7]. The unemployment rates of individuals aged 20-25 are around 10 percent for Mainland China. Less than 50 percent of them signed employment contract when they graduated and more than 20 percent were still hunting for jobs [4]. The situation is poorly bleak when the absolute number is considered. In 2013, the number of college graduates has almost reached 7 million, but 2 million of them did not know where to go after graduation [6].

Chinese career guidance and counseling for college students was implemented around 1998, when the higher education systems began to expand. In order to keep students' sustainable career development, all higher education institutions provided students with career related courses and training, namely six aspects of education and guidance. They are the awareness of career planning, self-career development, employability enhancement, guidance for job-hunting, occupation adaption and development, and the entrepreneurship education [8].

Moreover, various types of activities are carried out as forms of sustainable career guidance. For example, group training, classroom discussions, career-related case studies, mock interviews, group surveys, assessment tools and extracurricular experiences (e.g., experience sharing, internships, and business competitions). Although various kinds of guidance and service have been provided, university career counselors and scholars still questioned about their effectiveness [9-11]. Therefore, more studies are needed in this field. This is especially the case for those who want to find the "best practices" for university students.

Proposed and developed by Savickas [12-14], career construction theory (CCT) sharply captures the changes of world of work. Career in the $20^{\text {th }}$ century was objective $[15,16]$. People got jobs after they left school and stayed in one company for a lifelong time. Career was linear, and its trajectory could be predicted in the hierarchical organizations. Individuals showed their loyalty to the company by working hard and in return for this, the company was responsible for nurturing them [13].

Today, the rise of neoliberalism made individuals be responsible for their own careers [13]. The meaning of career has changed with the changes in the organizational structures, workforce demographics and the globalization of economy [17-19]. In respond to this, CCT has been proposed. It regarded career as stories which individuals describe their working life; individuals need to impose meanings to their careers. In other words, individuals need to subjectively construct their careers and become the author of their own life [13].

CCT believes that career is a lifelong process and individuals began to construct their careers since childhood [13]. They are the actors in this stage. By way of interacting in the family and imitating the significant others, usually parents, people began to construct their careers. They then adapt this role for use at school and the community, and they began to perform as agent, adapting to tasks, transitions and traumas they encountered in life. Finally, they become authors, writing their own autobiography that explains occupational experiences in a continuous and coherent way.

There are four components in this model, adaptive readiness, adaptability, adapting responses and adaptation results $[13,20]$. Adaptive readiness refers to one's personal characteristic of flexibility or willingness to deal with the tasks, transitions and traumas. It involves one's personality, goalorientation, values and self-cognition [13]. Adaptability refers to one's psychosocial resources that can be utilized in the career tasks, transitions and traumas [13]. Adapting responses refer to the 
vocational behaviors that one displays when dealing with tasks, transitions and traumas [13]. Adaption results usually refer to person-environment fit, career success and satisfaction [13, 21]. In this study, we focus on the university students' career adaptability and adaptive coping responses, that is, their career related self and environmental exploration.

Career adaptability is regarded as the core construct in CCT, and it has four components (a) feeling concerned about futures; (b) exerting personal control over vocational future; (c) showing curiosity in finding possible future selves; (d) boosting confidence to realize the dream [21]. Although the CCT views the career adaptability is influenced by the interplay between personal characteristics and environment individuals are embedded in, its original model only pays much attention to the personal features [13]. In other words, its original model only explicitly takes into account the personal characteristics, such as proactive personality, core-self evaluations, GPA, big-five personality, and optimism, and argue that it positively influence on the career adaptability [22-28].

The minor inconsistency between its theoretical assumption and model provides much opportunity for scholars to take. Lots of empirical studies have begun to identify the contextual factors that influence career adaptability. For example, by utilizing the longitudinal field quasiexperiment study and imposing external intervention, Koen found that university graduates' career adaptability could be greatly enhanced [29]. Guan found that a high level of parental engagement and a low level of parental interference would benefit Chinese undergraduates' career related exploration, which further improves their adaptability [30,31]. Ocampo found that supports from the spouse and organizations could also positively influence full-time employees' career adaptability, which further impact their subjective and objective career success [32]. Young people in China these days get lots of career related instructions and supports from universities; therefore, the purpose of this article is to investigate the relations between POS and career related self and environmental exploration.

This study utilizes the career construction model as the structural model to explore the relationship between perceived organizational support (POS), career adaptability and career-related self and environmental exploration to understand the impact that POS influence exerts on students' career exploration (i.e., self and environmental exploration). In addition, in order to respond to Rudolph's call to apply the career construction model to the marginalized groups [33], this study perform the multi-group comparisons to identify the relations among these constructs over gender, major and places of origins. Women, students who study the humanities and social sciences, and those from the rural areas, are traditionally seen as the disadvantaged groups compared to their counterparts [9-11]. Based on these discussions, we proposed the following research questions:

RQ1: What is the relationship between POS and students' career-related self-exploration and environmental exploration?

RQ2: How do male and female students' perspectives compare on the self and environmental careerrelated exploration?

RQ3: How do humanities and social science and science and engineering students' perspectives compare on the self and environmental career-related exploration?

RQ4: How do rural and urban students' perspectives compare on the self and environmental careerrelated exploration?

\section{Theoretical Background and Research Hypotheses}

\subsection{POS and career adaptability}


POS in our research is defined as the extent to which students assume that university cares about their values and well-being [34]. It is an experience-based attribution that students evaluate the university's policies, norms, procedures, and actions that may influence them [35]. POS meets the requirements of students' needs, providing help when it is needed [35]. Previous studies have proven that POS can influence factors that can contribute to career success [36, 37]. In other words, POS can influence career outcomes indirectly. Among all the mediation variables, such as employability [38], career satisfaction [32] and professional commitment [39], career adaptability is one of the important mediators that used a lot in empirical work $[32,40]$; therefore, the following hypothesis is proposed:

\section{H1: POS has the positive influence on career adaptability.}

\subsection{Career adaptability and career exploration}

Career adaptability is a psychosocial resources that an individual has in order to deal with current and future tasks, transitions and traumas [21]. It has four sub-competencies: be concern about one's vocational future; be in control their vocational career; display curiosity about possible career routines, and show confidence about their own ability to realize the vocational self [13, 21]. Empirical studies have shown that career adaptability has the positive impact on one's employability [41], challenging job demands and organizational career growth [42], academic satisfaction [43], low turnover intentions [44] and late career planning [45].

Career exploration can be divided into two categories: self-exploration (individuals understand who they are by exploring their own attributes) and environmental exploration (individuals seek career-related information, such as job features, organizations and vocational prospects) [46]. In our research, we propose that both types of career exploration can be facilitated by career adaptability for the following reasons. First, according to CCT, career adaptability has the positive influence on the career adapting responses and these two career related explorations can be seen as the important aspect of career adapting responses [14]. Second, some empirical studies have the found career exploration has the impact on the career adaptability [30,47], and meanwhile, the reciprocal nature of career adaptability construct has been confirmed [48]. In other words, we could either hypothesize that career exploration has the positive influence on the career adaptability, or the career adaptability has positively influence on the career exploration. Thus, the following hypotheses are proposed:

H2: Career adaptability has the positive influence on career-related self-exploration.

H3: Career adaptability has the positive influence on career-related environmental exploration.

\subsection{POS and career exploration}

Previous study has empirically proven that supports from parents, peers and teachers can promote one's career-related self and environmental exploration [49-51], which indicated the relations between contextual factors and career exploration. As POS is also one of the contextual factors which was employed a lot in many work [32,40], our study proposed that POS is conducive to career exploration, too. Specially, we proposed:

H4: POS has the positive influence on career-related self-exploration.

H5: POS has the positive influence on career-related environmental exploration. 


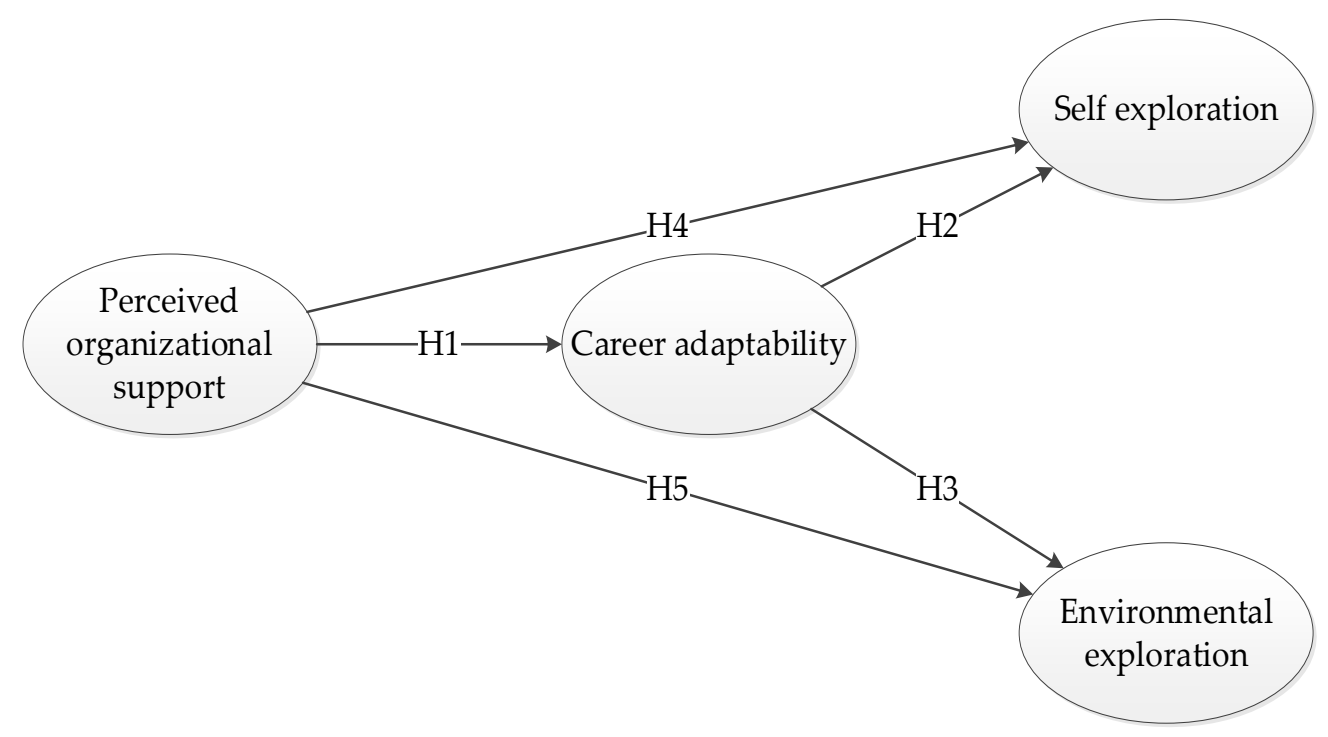

Figure1. Theoretical Framework

\section{Materials and Methods}

\subsection{Participants and procedure}

Data were collected from a university of science and technology located in the Northwest China. We approached our respondents with the help of counselors in each school and they forwarded our survey to the undergraduates. Participation was voluntary. Students were also encouraged to share this survey with their peers. In survey's instruction part, students were told that all the data was used for scientific purpose only and their personal information were treated as confidential. Students were allowed to quit from the survey, if they found some items are difficult to answer. In our final analysis, 611 undergraduates aged from 17 to 25 years (mean $=20.51$; SD = 1.70). The demographic of respondents was shown in the Table 1.

TABLE 1. DEMOGRAPHICS OF RESPONDENTS

\section{Characteristics}

Gender

Male

Female

Major

Humanities \& Social Sciences

Science \& Engineering

\section{Parental Educational Level}

Primary certificate or below

Junior or senior high school 


\begin{tabular}{lcc} 
Characteristics & Frequency & Percent (\%) \\
\hline Perceived Social Class & & \\
Working class & 179 & $29.3 \%$ \\
Middle class & 367 & $60.1 \%$ \\
Upper class & 65 & $10.6 \%$ \\
Area & & \\
Urban area & 175 & $28.6 \%$ \\
Rural area & 436 & $71.4 \%$ \\
University grade & & \\
Freshman & 219 & $35.8 \%$ \\
Sophomore & 170 & $27.8 \%$ \\
Junior & 88 & $14.4 \%$ \\
Senior & 134 & $21.9 \%$ \\
\hline
\end{tabular}

\subsection{Measures}

\subsubsection{POS}

The POS was measured by an eight-item short form developed by Eisenberger [34]. A sample item is: "My organization strongly considered my goals and values". Respondents were asked to rate on a 7-point Likert-type scale (support items: $1=$ strongly disagree; $7=$ strongly agree). The reliability coefficient for this scale was 0.81 and current one was 0.91 .

\subsubsection{Student career adaptability}

The Career Adapt-Abilities Scale was utilized to measure the students career adaptability[21]. The total score represents students' career adaptabilities and four factors specifically reflect students' adaptability resources-concern, control, curiosity and confidence. Each factor has 6 items, with 24 in total. Previous studies have shown its excellent validity and reliability, including in the Chinese samples [27, 28]. In this study, the Cronbach's alpha coefficient is 0.92 .

\subsubsection{Career exploration}

The career exploration was measured by the scale developed by Stumpf [46], with 5 items on the self-exploration and 6 items on the environment exploration. The scale was utilized in the Chinese context previously, and demonstrated a good reliability [47, 52]. A sample item for the career-related self-exploration is: "I reflected on my past integrates with my future career". Career-related environmental exploration is: "I went to various career orientation programs". Respondents were asked to rate on these 11 items from 1 (strongly disagree) to 5 (strongly agree). In this study, the Cronbach's alpha coefficients are both 0.86 for the self and environmental exploration.

\subsection{Data analysis}


Our analysis followed the two-step approach of Structural Equation Modeling suggested by Anderson and Gerbing [53]. First, the Confirmatory Factor Analysis (CFA) was used to check the measurement model and then the path effects and significance were examined by the structural model. Then, the Sobel test [54] and biased-corrected and percentile bootstrapping (the product-ofcoefficient method proposed by Mackinnon et al.) [55] were used to assess the magnitude and significance of the mediating effects of career adaptability. Finally, a multi-group SEM analysis was performed to compare the hypothesized predictions and mediations among the variables across gender (i.e., female and male), major (i.e., Humanities and Social Sciences and Science and Engineering) and areas (i.e., rural and urban China).

\section{Results}

\subsection{Measurement model}

We first check the reliability of our data. All the values of Cronbach's $\alpha$ and composite reliability exceeded 0.7 and the factor loadings exceeded 0.6 , suggesting the satisfactory reliability and internal consistency [56]. Table 2 also showed that the study has met the general requirement of convergent validity. We then check the discriminant validity of our data and Table 3 displayed the results. Followed by the Fornell and Larcker's suggestion [57], if the square root of the average of variance extracted (AVE) is larger than the Pearson correlation of constructs, it means that the criteria of discriminant validity met.

TABLE 2. STANDARDIZED LOADINGS AND RELIABILITIES

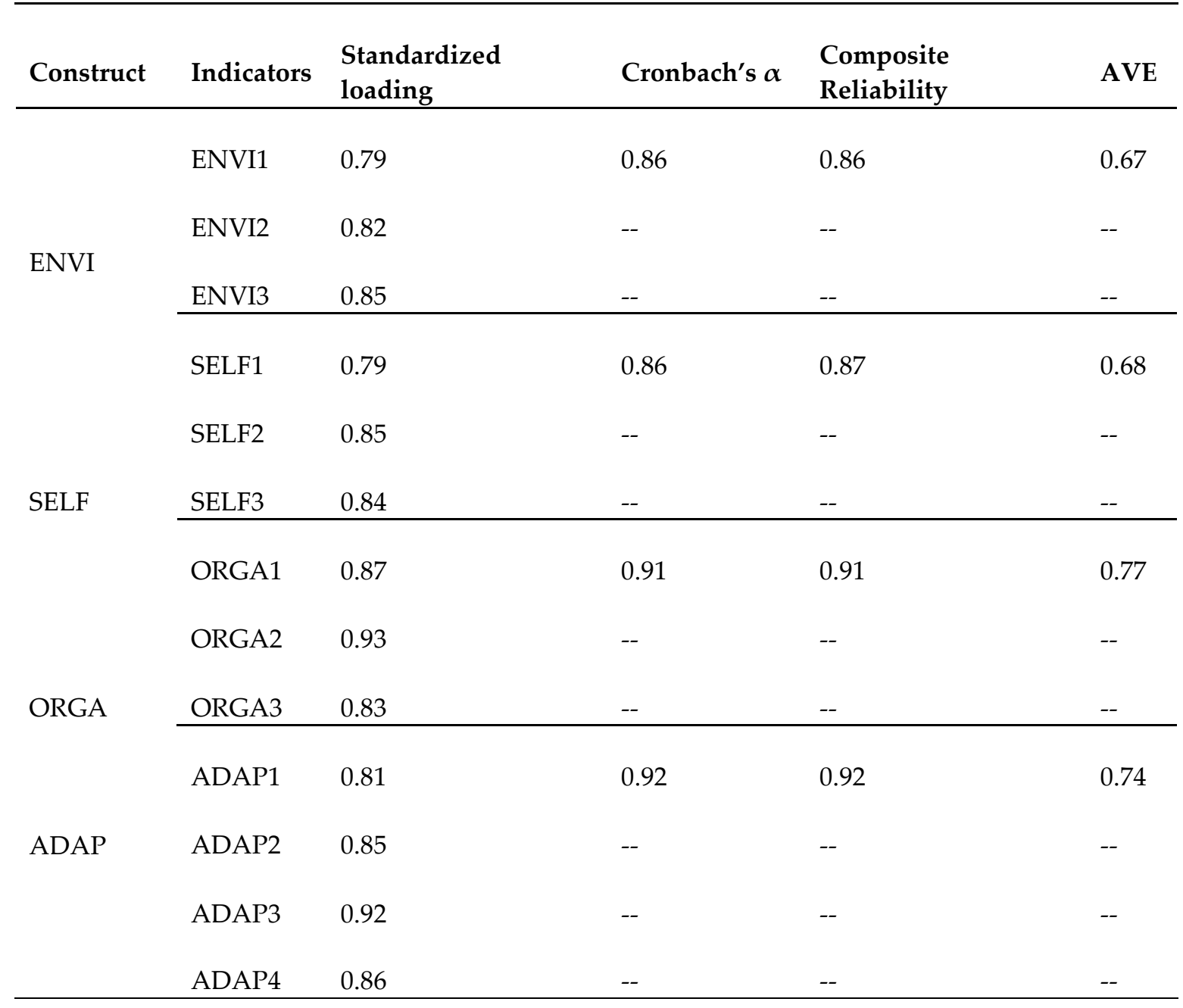




\begin{tabular}{|c|c|c|c|c|c|}
\hline Construct & Indicators & $\begin{array}{l}\text { Standardized } \\
\text { loading }\end{array}$ & Cronbach's $\alpha$ & $\begin{array}{l}\text { Composite } \\
\text { Reliability }\end{array}$ & AVE \\
\hline
\end{tabular}

Note: ENVI=environmental exploration; $\mathrm{SELF}=$ self-exploration; ORGA=organizational support; ADAP=adaptability

Third, we performed the common method variance (CMV) test [58, 59]. The self-reported survey in a single setting was often criticized for its limited internal validity. We used the Harman one-factor test to check the issue of CMV. The CFA was conducted by putting all measurement items into a oneconstruct model, the results of which suggested a deteriorated model fit with $\chi 2 /$ d.f. $=31.18$, goodness of fit index $(\mathrm{GFI})=0.61$, comparative fit index $(\mathrm{CFI})=0.66$, normed fit index $(\mathrm{NFI})=0.65$, and rootedmean-squared error of approximation $($ RMSEA $)=0.22$. The diagnostic measure confirmed that CMV is unlikely in this empirical data.

Finally, goodness-of-fit criteria for the measurement model was evaluated, and it means that the proposed theoretical model could explain the empirical data well. Table 4 demonstrates that the overall goodness-of-fit criteria reached the satisfactory level suggested in the literature.

TABLE 3. CORRELATION COEFFICIENT MATRIX

\begin{tabular}{lccccccc}
\hline & Mean & S.D. & AVE & ENVI & SELF & ORGA & ADAP \\
\hline ENVI & 3.21 & 0.91 & 0.67 & 0.82 & & & \\
SELF & 3.55 & 0.80 & 0.68 & 0.71 & 0.82 & & \\
ORGA & 4.53 & 1.40 & 0.77 & 0.51 & 0.46 & 0.88 & \\
ADAP & 5.68 & 1.03 & 0.74 & 0.61 & 0.70 & 0.47 & 0.86 \\
\hline
\end{tabular}

Note 1: ENVI=environmental exploration; $S E L F=$ self-exploration; ORGA=organizational support; ADAP=adaptability.

Note 2: Off-diagonal elements are the square root of average of variance extracted (AVE).

TABLE 4. GOODNESS-OF-FIT INDICES FOR THE MEASUREMENT SCALES

\begin{tabular}{llll} 
Fit index & Recommended Value & Measurement model & Structural model \\
\hline Chi-square/ d.f. & $\leq 5$ & 3.49 & 4.81 \\
GFI & $\geq 0.90$ & 0.95 & 0.93 \\
CFI & $\geq 0.92$ & 0.97 & 0.96 \\
NFI & $\geq 0.90$ & 0.96 & 0.95 \\
IFI & $\geq 0.90$ & 0.97 & 0.96 \\
TLI & $\geq 0.90$ & 0.97 & 0.95 \\
RFI & $\geq 0.90$ & 0.95 & 0.94
\end{tabular}




\begin{tabular}{llcc} 
PGFI & $\geq 0.50$ & 0.62 & 0.61 \\
PCFI & $\geq 0.50$ & 0.74 & 0.74 \\
PNFI & $\geq 0.50$ & 0.73 & 0.73 \\
SRMR & $\leq 0.08$ & 0.04 & 0.06 \\
RMSEA & $\leq 0.08$ & 0.06 & 0.08 \\
\hline
\end{tabular}

\subsection{Structural model}

Structural model test is performed to evaluate the hypothesis in our proposed model. Table 4 illustrated that the empirical data has met the model fit criteria suggested by the scholars. Table 5 showed the properties of the research hypothesis, including the standardized path coefficients and the results of hypothesis testing. All the proposed hypotheses are supported.

TABLE 5. SUMMARY OF HYPOTHESES TESTING RESULTS

\begin{tabular}{|c|c|c|c|c|c|}
\hline \multicolumn{2}{|c|}{ Hypotheses } & \multirow{2}{*}{\multicolumn{2}{|c|}{$\begin{array}{l}\begin{array}{l}\text { Standardized path } \\
\text { coefficients }\end{array} \\
0.47^{* * *}\end{array}$}} & \multirow{2}{*}{$\begin{array}{l}\text { t-value } \\
11.20\end{array}$} & \multirow{2}{*}{$\begin{array}{l}\text { Supported } \\
\text { Yes }\end{array}$} \\
\hline H1 & ORGA $\rightarrow$ ADAP & & & & \\
\hline $\mathrm{H} 2$ & $\mathrm{ADAP} \rightarrow \mathrm{SELF}$ & $0.64^{* * *}$ & & 13.61 & Yes \\
\hline H3 & $\mathrm{ADAP} \rightarrow$ ENVI & $0.50^{* * *}$ & & 10.84 & Yes \\
\hline $\mathrm{H} 4$ & ORGA $\rightarrow$ SELF & $0.17^{* * *}$ & & 4.13 & Yes \\
\hline H5 & ORGA $\rightarrow$ ENVI & $0.28^{* * *}$ & & 6.46 & Yes \\
\hline
\end{tabular}

Note 1: ENVI=environmental exploration; SELF=self-exploration; ORGA=organizational support; ADAP=adaptability.

Note 2: ${ }^{* * * *} p$-value $<0.001$

\subsection{Mediation results}

Sobel test was used to check the mediation effect of career adaptability. We also performed the biased-corrected and percentile bootstrapping to evaluate the magnitude and significance of the mediating effect of career adaptability. We computed the means of 2000 estimated indirect effects by creating 2000 bootstrap samples to get its $95 \%$ confidence interval (CI) of the estimates of the indirect effects being tests. Table 6 showed the results of Sobel test, with the z-value 9.60 ( $p$-value $<0.001)$. Its 95\% CI did not include zero, confirming its indirect effect. Moreover, by performing the selfprogramming AMOS, we also checked whether the career adaptability fully mediates the relation between POS and students' career exploration. Table 7 showed its results and both direct and indirect did not include zero, indicting the partial mediation effect of career adaptability.

TABLE 6. MEDIATION TESTS

\begin{tabular}{|c|c|c|c|c|c|}
\hline $\mathrm{Equ}$ & Relationship & $\begin{array}{l}\text { Unstandardized } \\
\text { Regression }\end{array}$ & $\begin{array}{l}\text { Standard } \\
\text { Error }\end{array}$ & $\begin{array}{l}\text { Sobel } \\
\text { Test (z- }\end{array}$ & $\begin{array}{l}95 \% \text { Asymmetric } \\
\text { confidence interval }\end{array}$ \\
\hline
\end{tabular}


H10a: ORGA-ADAP-

ORGA-ADAP 0.93

SELF

ADAP-

SELF

0.17

0.08

$9.60^{* * *} \quad(0.12,0.21)$

Note 1: ENVI=environmental exploration; $S E L F=$ self-exploration; ORGA=organizational support; ADAP=adaptability.

Note 2: ${ }^{*} p$-value $<0.05 ;{ }^{* * *} p$-value $<0.01$; ${ }^{* * * *} p$-value $<0.001$

TABLE 7. DIRECT, INDIRECT AND TOTAL EFFECTS

\begin{tabular}{|c|c|c|c|c|c|c|c|}
\hline \multirow{2}{*}{ Path } & \multirow{2}{*}{ Point estimation } & \multicolumn{2}{|c|}{ Product of coef. } & \multicolumn{2}{|c|}{ Biased-corrected } & \multicolumn{2}{|c|}{ Percentile } \\
\hline & & SE & $\mathrm{Z}$ & Lower & Upper & Lower & Upper \\
\hline Indirect & 0.16 & 0.02 & 8.00 & 0.12 & 0.21 & 0.12 & 0.21 \\
\hline Direct & 0.09 & 0.03 & 3.00 & 0.04 & 0.14 & 0.04 & 0.14 \\
\hline Total & 0.25 & 0.03 & 8.33 & 0.19 & 0.31 & 0.19 & 0.31 \\
\hline
\end{tabular}

\subsection{Multi-group analysis}

Three constructs may have the moderating effects in this model. Therefore, the present study examined the effects of various gender, major and places of origin subgroup concerns in career construction model via multi-group comparisons. The main purpose of multi-group analysis test was to assess whether the path coefficients were different across the two gender subgroups, two major subgroups and two places of origin subgroups. To test the multiple group comparison, we utilized the analytical strategy of $\mathrm{Wu}[60]$ and $\mathrm{Gu}[61]$ to evaluate the multiple group difference on the structural model. The test results for structural models and subgroup analysis are illustrated in Table 8, 9 and 10. Based on the subgroup analysis in Table 8, the effect of POS on career-related environmental exploration is confirmed to differ according to the gender while the remaining paths are not. In Table 9, the effects of POS on career adaptability and the effects of POS on the careerrelated self -exploration are confirmed to differ based on the major while the rest paths are the not. In Table 10, none of the moderating effects is found. The results of the multiple group test demonstrated that the path coefficients were not significantly different in the $\chi 2$ testing between those who are from rural and urban areas.

For the female subgroup, the POS almost had no impact on their self and environmental exploration. For the relationship between POS and career-related self and environmental exploration, male subgroup had the much higher and also statistically significant path coefficients compared to their female counterparts. For the students who majored in the humanities and social sciences, they perceived less but statistically significant organizational support than their science and engineering counterparts in terms of the environmental exploration. For those in the humanities and social sciences, the POS almost had no influence on their career related self- exploration.

\section{TABLE 8. PATH COEFFICIENTS AND $\chi 2$ DIFFERENCE ACROSS GENDER}

Path

\section{Subgroup comparison}

Path

M-group F-group $\quad \begin{aligned} & \text { (Uncons } \\ & \text { (f) }\end{aligned}$ 


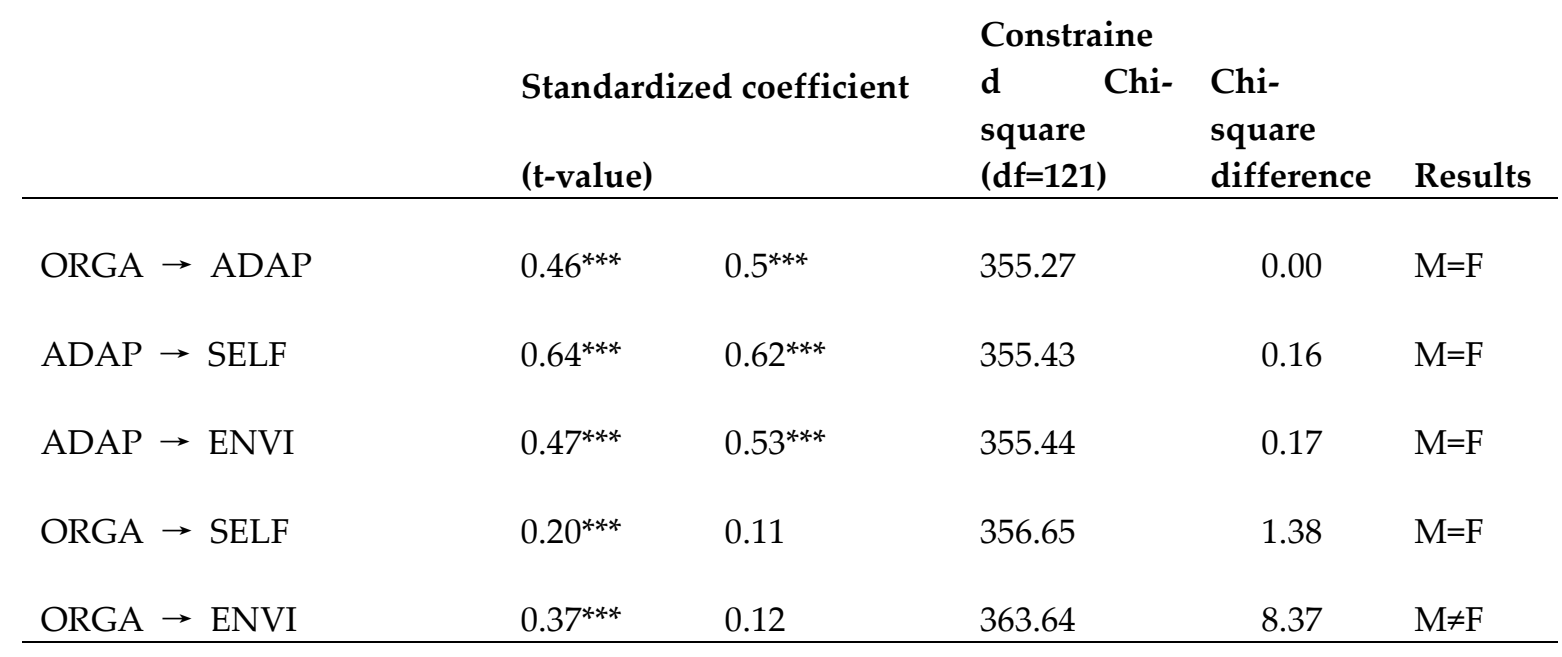

Notes: M, male group; F, female group; ${ }^{* * *} p$-value $<0.001$

TABLE 9. PATH COEFFICIENTS AND $\chi 2$ DIFFERENCE ACROSS MAJOR

\begin{tabular}{|c|c|c|c|c|c|}
\hline \multirow[b]{2}{*}{ Path } & \multirow{2}{*}{\multicolumn{2}{|c|}{$\begin{array}{l}\text { H-Group S-Group } \\
\text { Standardized coefficient } \\
\text { (t-value) }\end{array}$}} & \multicolumn{3}{|c|}{$\begin{array}{l}\text { Subgroup comparison } \\
\text { (Unconstrained } X 2=365.00, \mathrm{df}=120 \text { ) }\end{array}$} \\
\hline & & & \multicolumn{2}{|c|}{$\begin{array}{ll}\text { Constraine } & \\
d \quad \quad \text { Chi- } & \text { Chi- } \\
\text { square } & \text { square } \\
(\mathrm{df}=121) & \text { difference }\end{array}$} & Results \\
\hline ORGA $\rightarrow$ ADAP & $0.52^{* * *}$ & $0.42^{* * *}$ & 369.78 & 4.78 & $H \neq S$ \\
\hline $\mathrm{ADAP} \rightarrow \mathrm{SELF}$ & $0.73^{* * *}$ & $0.59^{* * *}$ & 365.14 & 0.14 & $\mathrm{H}=\mathrm{S}$ \\
\hline $\mathrm{ADAP} \rightarrow \mathrm{ENVI}$ & $0.56^{* * *}$ & $0.46^{* * *}$ & 366.19 & 1.19 & $\mathrm{H}=\mathrm{S}$ \\
\hline ORGA $\rightarrow$ SELF & 0.04 & $0.23^{* * *}$ & 369.89 & 4.89 & $H \neq S$ \\
\hline ORGA $\rightarrow$ ENVI & $0.18^{*}$ & $0.34^{* * *}$ & 366.59 & 1.59 & $\mathrm{H}=\mathrm{S}$ \\
\hline
\end{tabular}

Notes: H, humanities and social science group; $S$, science and engineering group; ${ }^{* * *} p$-value $<0.001$; ${ }^{*} p$-value $<0.05$

\begin{tabular}{|c|c|c|c|c|c|}
\hline \multirow[b]{4}{*}{ Path } & \multirow{3}{*}{ R-Group } & & \multicolumn{3}{|c|}{ Subgroup comparison } \\
\hline & & U-Group & \multicolumn{3}{|c|}{ (Unconstrained $\mathrm{X} 2=369.45, \mathrm{df}=120$ ) } \\
\hline & & & \multicolumn{3}{|l|}{ Constraine } \\
\hline & \multicolumn{2}{|c|}{ Standardized coefficient } & $\begin{array}{l}\text { d Chi- } \\
\text { square } \\
(\mathrm{df}=121)\end{array}$ & $\begin{array}{l}\text { Chi- } \\
\text { square } \\
\text { difference }\end{array}$ & Results \\
\hline
\end{tabular}




\begin{tabular}{lccccc}
\hline ORGA $\rightarrow$ ADAP & $0.51^{* * *}$ & $0.41^{* * *}$ & 371.38 & 1.92 & $\mathrm{R}=\mathrm{U}$ \\
$\mathrm{ADAP} \rightarrow$ SELF & $0.58^{* * *}$ & $0.72^{* * *}$ & 371.49 & 2.04 & $\mathrm{R}=\mathrm{U}$ \\
$\mathrm{ADAP} \rightarrow$ ENVI & $0.51^{* * *}$ & $0.48^{* * *}$ & 370.94 & 1.48 & $\mathrm{R}=\mathrm{U}$ \\
ORGA $\rightarrow$ SELF & $0.19^{* * *}$ & $0.16^{*}$ & 369.66 & 0.21 & $\mathrm{R}=\mathrm{U}$ \\
ORGA $\rightarrow$ ENVI & $0.25^{* * *}$ & $0.32^{* * *}$ & 369.45 & 0.00 & $\mathrm{R}=\mathrm{U}$ \\
\hline
\end{tabular}

Note: $\mathrm{R}$, rural group; $\mathrm{U}$, urban group; ${ }^{* * *} p$-value $<0.001$; ${ }^{*} p$-value $<0.05$

\section{Discussion}

In the updated Agenda 2030, the aim of the Goal 8 of the Sustainable Development Goals is to promote sustained, inclusive and sustainable economic growth, full and productive employment and decent work for all people [62]. The vision may be shattered with the growing youth unemployment worldwide. Based on this macro background, the aim of this study was to examine the relationship between POS, career adaptability and self and environmental career exploration; the study also aimed to perform the multiple group comparison analysis to identity the relationships among proposed model over gender, major and places of origin subgroups. The results of this study revealed that perceived organizational support could directly influence individuals' self and environmental career exploration and also indirectly influence them via career adaptability. The results also showed that gender and major are the moderating variables for the proposed model. These findings carry implications for POS and career adaptability literature.

\subsection{Theoretical implications}

First, our study expands our understanding of the role of POS in students' career exploration. Although lots of previous studies have focused on the impact of POS, many of the respondents of them are the employees [36-38, 63-66]. Moreover, many of them are conducted in the Western context $[36,38,66,67]$. Our research is among the first studies to clearly and systematically evaluate the POS and career exploration among the university students in China, which is famous for its collective culture [68].

Second, inspired by the career construction theory, present study also examined the mechanism underlying the constructs between POS and career related exploration. Although university these days provides lots of support for students' university to work transition, no attention has been paid to clarifying its underlying mechanisms. A popular view is that POS could strength students' social network, which could contribute to their job searches [69-71]. Our findings clearly demonstrate that POS could enhance students' career adaptability, and further improve their career exploration. While our findings shed light on the effects of POS, more research is still needed. For example, POS may improve the contextual climates (caring and task-involving), which further influence students' career adaptability and career exploration.

Third, our investigation contributes to the literature on the career construction theory by illustrating the role of organizational intervention in enhancing students' career adaptability. Most studies on career construction theory have focused on the personal traits [26, 72-75]. Even those who have paid attention to the importance of contextual factors, they still focused on the supports from the peers, parents and teachers [1, 30, 76-78]. In other words, the relational support is their focus. Our findings showed that another type of contextual support, supports from the universities, could also be one of the primary sources that could contribute to the positive career development. 


\subsection{Practical implications}

Vocational counselors in the university should be aware that POS is conducive to students' career adaptability and career exploration, but several aspects of our findings in regard to the practical implications should be emphasized: first, although lots of initiatives have been taken to facilitate students' university to work transition, the effect of these programs is still too difficult to evaluate [911]. Our findings could shed light on this issue. From the results of multi-group comparison, we could observe that student groups are quite diverse. They can be assigned into different categories, based on gender, major and places of origin. For different groups, the influence of POS on their career related explorations is different. For example, for the gender subgroups, the POS had no impact on the career-exploration for the female students.

Similarly, for the major subgroups, the POS had no impact on the self-exploration for those who majored the humanities and social sciences in the university of technology and science. The results suggest that POS is especially important for those who are at the disadvantaged positions. Educators should take this group level difference into account when designing or implementing career training programs to students. In other words, one size does not fit all; the programs who aim to enhance students' sustainable career development should be tailored in order to meet various needs of students [2].

Second, four dimensions of career adaptability (concern, control, curiosity and confidence) could be targeted at in order to stimulate students' career related self and environmental exploration. Career adaptability scales could be utilized to assess the level of students' career adaptability, and based on the results of each component, students' career adaptability could be enhanced accordingly. Curriculums, adaptabilities and career related behaviors, such as explorations, could be well collected. Previous studies have demonstrated the effectiveness of problem-based learning in promoting students five sustainability competencies that are valued in the workplace [79].

\subsection{Limitations and directions for future research}

The current study has some limitations. For the methodology part, the study may have the common method bias because single questionnaire was used to measure all constructs, and this may influence the strength of the hypothesized relationships among these dimensions. Therefore, we suggest that future research should employ various instruments besides the single-source self-report methodology to get the data [60]. Second, the relationships among these constructs cannot be assumed to be causal, and future studies should use time-lagged panel design or an experimental design to check their causality [80]. Third, due to the sampling strategy, the findings of this study should be cautiously interpreted. We conducted the research in a university of science and technology located in the Northwest China. Future study should check whether the findings could be applied to other types of university (e.g., comprehensive university, normal university and liberal arts university).

\section{Reference}

Author Contributions: Conceptualization, Y. M. and S.-C. C.; methodology, Y. M.; validation, Y. M. and S.-C.; investigation, Y. M.; writing-original draft preparation, Y. M., S.-C. C. and A. R.; writing-review and editing, A. R.; supervision, A. R. All authors have read and agreed to the published version of the manuscript.

Funding: This research received no external funding.

Conflicts of Interest: The authors declare no conflict of interest.

\section{References}


1. Renn, R. W.; Steinbauer, R.; Taylor, R.; Detwiler, D., School-to-work transition: Mentor career support and student career planning, job search intentions, and self-defeating job search behavior. Journal of Vocational Behavior 2014, 85, (3), 422-432.

2. Okay-Somerville, B.; Allison, I.; Luchinskaya, D.; Scholarios, D., Disentangling the impact of social disadvantage on 'becoming employable': evidence from STEM student university-to-work transitions. Studies in Higher Education 2020.

3. Liu, Y.; Green, A.; Pensiero, N., Expansion of higher education and inequality of opportunities: a crossnational analysis. Journal of Higher Education Policy and Management 2016, 38, (3), 242-263.

4. Mok, K. H.; Jiang, J., Massification of higher education and challenges for graduate employment and social mobility: East Asian experiences and sociological reflections. International Journal of Educational Development 2018, 63, 44-51.

5. Zha, Q., China's move to mass higher education in a comparative perspective. Compare-a Journal of Comparative and International Education 2011, 41, (6), 751-768.

6. Chan, W. K., Higher education and graduate employment in China: Challenges for sustainable development. Higher Education Policy 2015, 28, (1), 35-53.

7. Wu, L. L.; Yan, K.; Zhang, Y. Q., Higher education expansion and inequality in educational opportunities in China. Higher Education 2020.

8. Education, G. O. o. t. M. o., College students' career development and employment guidance curriculum requirements (Publication No.2007-7). In The Ministry of Education of the People's Republic of China: Beijing, 2007.

9. Zhou, X.; Li, X.; Gao, Y., Career guidance and counseling in Shanghai, China: 1977 to 2015. The Career Development Quarterly 2016, 64, (3), 203-215.

10. Hao, D.; Sun, V. J.; Yuen, M., Towards a model of career guidance and counseling for university students in China. International Journal for the Advancement of Counselling 2015, 37, (2), 155-167.

11. Zhang, W.; Hu, X.; Pope, M., The evolution of career guidance and counseling in the People's Republic of China. The Career Development Quarterly 2002, 50, (3), 226-236.

12. Savickas, M. L., The theory and practice of career construction. In Career development and counseling: Putting theory and research to work,, Brown, S. D.; Lent, R. W., Eds. Hokoben, NJ: Wiley, 2005; pp 42-70.

13. Savickas, M. L., Career construction theory and practice. In Career development and counselling: Putting theory and research into work, 2nd ed.; Lent, R. W.; Brown, S. D., Eds. Hoboken, NJ: Wiley, 2013; pp 147-183.

14. Savickas, M. L.; Porfeli, E. J.; Hilton, T. L.; Savickas, S., The student career construction inventory. Journal of Vocational Behavior 2018, 106, 138-152.

15. Super, D. E., The psychology of careers. NY: Harper \& Row: New York, 1957.

16. Super, D. E., Career development: Self-concept theory. 1963.

17. Baruch, Y.; Rousseau, D. M., Integrating psychological contracts and ecosystems in career studies and management. Academy of Management Annals 2019, 13, (1), 84-111.

18. Hirschi, A., The fourth industrial revolution: Issues and implications for career research and practice. The Career Development Quarterly 2018, 66, (3), 192-204. 
19. Brynjolfsson, E.; McAfee, A., The second machine age: Work, progress, and prosperity in a time of brilliant technologies. W. W. Norton: New York, NY, 2014.

20. Savickas, M. L., Career adaptability: An integrative construct for life-span, life-space theory. The Career Development Quarterly 1997, 45, (3), 247-259.

21. Savickas, M. L.; Porfeli, E. J., Career adapt-abilities scale: Construction, reliability, and measurement equivalence across 13 countries. Journal of Vocational Behavior 2012, 80, (3), 661-673.

22. Li, Y. H.; Guan, Y.; Wang, F. X.; Zhou, X.; Guo, K.; Jiang, P.; Mo, Z. C.; Li, Y. M.; Fang, Z., Big-five personality and BIS/BAS traits as predictors of career exploration: The mediation role of career adaptability. Journal of Vocational Behavior 2015, 89, 39-45.

23. Fang, W.; Zhang, Y.; Mei, J.; Chai, X.; Fan, X., Relationships between optimism, educational environment, career adaptability and career motivation in nursing undergraduates: A cross-sectional study. Nurse Education Today 2018, 68, 33-39.

24. Perera, H. N.; McIlveen, P., The role of optimism and engagement coping in college adaptation: A career construction model. Journal of Vocational Behavior 2014, 84, (3), 395-404.

25. Zacher, H., Career adaptability predicts subjective career success above and beyond personality traits and core self-evaluations. Journal of Vocational Behavior 2014, 84, (1), 21-30.

26. Šverko, I.; Babarović, T., Applying career construction model of adaptation to career transition in adolescence: A two-study paper. Journal of Vocational Behavior 2019, 111, 59-73.

27. Guan, Y.; Dai, X.; Gong, Q.; Deng, Y.; Hou, Y.; Dong, Z.; Wang, L.; Huang, Z.; Lai, X., Understanding the trait basis of career adaptability: A two-wave mediation analysis among Chinese university students. Journal of Vocational Behavior 2017, 101, 32-42.

28. Pan, J.; Guan, Y.; Wu, J.; Han, L.; Zhu, F.; Fu, X.; Yu, J., The interplay of proactive personality and internship quality in Chinese university graduates' job search success: The role of career adaptability. Journal of Vocational Behavior 2018, 109, 14-26.

29. Koen, J.; Klehe, U. C.; Van Vianen, A. E. M., Training career adaptability to facilitate a successful school-towork transition. Journal of Vocational Behavior 2012, 81, (3), 395-408.

30. Guan, Y.; Wang, F.; Liu, H.; Ji, Y.; Jia, X.; Fang, Z.; Li, Y.; Hua, H.; Li, C., Career-specific parental behaviors, career exploration and career adaptability: A three-wave investigation among Chinese undergraduates. Journal of Vocational Behavior 2015, 86, 95-103.

31. Guan, Y.; Wang, Z.; Gong, Q.; Cai, Z. J.; Xu, S. L.; Xiang, Q.; Wang, Y.; Chen, S. X.; Hu, H. L.; Tian, L., Parents' career values, adaptability, career-specific parenting behaviors, and undergraduates' career adaptability. Counseling Psychologist 2018, 46, (7), 922-946.

32. Ocampo, A. C. G.; Restubog, S. L. D.; Liwag, M. E.; Wang, L.; Petelczyc, C., My spouse is my strength: Interactive effects of perceived organizational and spousal support in predicting career adaptability and career outcomes. Journal of Vocational Behavior 2018, 108, 165-177.

33. Rudolph, C. W.; Zacher, H.; Hirschi, A., Empirical developments in career construction theory. Journal of Vocational Behavior 2018, 111, 1-6.

34. Eisenberger, R.; Huntington, R.; Hutchison, S.; Sowa, D., Perceived organizational support. Journal of Applied Psychology 1986, 71, (3), 500-507. 
35. Eisenberger, R.; Armeli, S.; Rexwinkel, B.; Lynch, P. D.; Rhoades, L., Reciprocation of perceived organizational support. Journal of Applied Psychology 2001, 86, (1), 42-51.

36. Tolentino, L. R.; Garcia, P. R. J. M.; Restubog, S. L. D.; Scott, K. L.; Aquino, K., Does domestic intimate partner aggression affect career outcomes? The role of perceived organizational support. Human Resource Management 2017, 56, (4), 593-611.

37. Liu, J.; Liu, Y. h., Perceived organizational support and intention to remain: The mediating roles of career success and self-esteem. International journal of nursing practice 2016, 22, (2), 205-214.

38. Guilbert, L.; Carrein, C.; Guenole, N.; Monfray, L.; Rossier, J.; Priolo, D., Relationship between perceived organizational support, proactive personality, and perceived employability in workers over 50. Journal of Employment Counseling 2018, 55, (2), 58-71.

39. Zheng, J. W.; Wu, G. D., Work-family conflict, perceived organizational support and professional commitment: A mediation mechanism for Chinese project professionals. International Journal of Environmental Research and Public Health 2018, 15, (2).

40. Guan, Y.; Yang, W.; Zhou, X.; Tian, Z.; Eves, A., Predicting Chinese human resource managers' strategic competence: Roles of identity, career variety, organizational support and career adaptability. Journal of Vocational Behavior 2016, 92, 116-124.

41. Kwon, J. E., Work volition and career adaptability as predictors of employability: Examining a moderated mediating process. Sustainability 2019, 11, (24).

42. Ingusci, E.; Spagnoli, P.; Zito, M.; Colombo, L.; Cortese, C. G., Seeking challenges, individual adaptability and career growth in the relationship between workload and contextual performance: A two-wave study. Sustainability 2019, 11, (2).

43. Ma, Y.; Chen, S. C.; Zeng, H., Male student nurses need more support: Understanding the determinants and consequences of career adaptability in nursing college students. Nurse Education Today 2020, 91.

44. Zhu, F.; Cai, Z.; Buchtel, E.; Guan, Y., Career construction in social exchange: a dual-path model linking career adaptability to turnover intention. Journal of Vocational Behavior 2019.

45. Fasbender, U.; Wöhrmann, A. M.; Wang, M.; Klehe, U.-C., Is the future still open? The mediating role of occupational future time perspective in the effects of career adaptability and aging experience on late career planning. Journal of Vocational Behavior 2019, 111, 24-38.

46. Stumpf, S. A.; Colarelli, S. M.; Hartman, K., Development of the career exploration survey (CES). Journal of Vocational Behavior 1983, 22, (2), 191-226.

47. Guan, Y.; Liu, S. M.; Guo, M. J.; Li, M. Y.; Wu, M. Y.; Chen, S. X.; Xu, S. L.; Tian, L., Acculturation orientations and Chinese student Sojourners' career adaptability: The roles of career exploration and cultural distance. Journal of Vocational Behavior 2018, 104, 228-239.

48. Guan, Y.; Zhuang, M.; Cai, Z.; Ding, Y.; Wang, Y.; Huang, Z.; Lai, X., Modeling dynamics in career construction: Reciprocal relationship between future work self and career exploration. Journal of Vocational Behavior 2017, 101, 21-31.

49. Cheung, R.; Arnold, J., Antecedents of career exploration among Hong Kong Chinese university students: Testing contextual and developmental variables. Journal of Vocational Behavior 2010, 76, (1), 25-36.

50. Turan, E.; Çelik, E.; Turan, M. E., Perceived social support as predictors of adolescents' career exploration. Australian Journal of Career Development 2014, 23, (3), 119-124. 
51. Hirschi, A.; Niles, S. G.; Akos, P., Engagement in adolescent career preparation: Social support, personality and the development of choice decidedness and congruence. Journal of Adolescence 2011, 34, (1), 173-182.

52. Cai, Z.; Guan, Y.; Li, H.; Shi, W.; Guo, K.; Liu, Y.; Li, Q.; Han, X.; Jiang, P.; Fang, Z., Self-esteem and proactive personality as predictors of future work self and career adaptability: An examination of mediating and moderating processes. Journal of Vocational Behavior 2015, 86, 86-94.

53. Anderson, J. C.; Gerbing, D. W., Structural equation modeling in practice: A review and recommended two-step approach. Psychological Bulletin 1988, 103, (3), 411-23.

54. Sobel, M. E., Asymptotic confidence intervals for indirect effects in structural equation models. Sociological Methodology 1982, 13, 290-312.

55. MacKinnon, D. P.; Fritz, M. S.; Williams, J.; Lockwood, C. M., Distribution of the product confidence limits for the indirect effect: program PRODCLIN. Behavior Research Methods 2007, 39, (3), 384-389.

56. Byrne, B. M., Structural equation modeling with AMOS: Basic concepts, applications, and programming. 3nd ed.; Routledge: 2016.

57. Fornell, C.; Larcker, D. F., Evaluating structural equation models with unobservable variables and measurement error. Journal of Marketing Research 1981, 18, (1), 39-50.

58. Podsakoff, P. M.; Organ, D. W., Self-reports in organizational research: Problems and prospects. Journal of management 1986, 12, (4), 531-544.

59. Mossholder, K. W.; Bennett, N.; Kemery, E. R.; Wesolowski, M. A., Relationships between bases of power and work reactions: The mediational role of procedural justice. Journal of Management 1998, 24, (4), 533-552.

60. Wu, C. H.; Chen, S. C., Understanding the relationships of critical factors to Facebook educational usage intention. Internet Research 2015, 25, (2), 262-278.

61. Gu, J. C.; Fan, L.; Suh, Y. H.; Lee, S. C., Comparing utilitarian and hedonic usefulness to user intention in multipurpose information systems. Cyberpsychology Behavior and Social Networking 2010, 13, (3), 287-297.

62. Nations, U. Sustainable development goals: Progress of goal 8 in 2019. https://sdgs.un.org/goals/goal8 (16 July),

63. Karatepe, O. M., Perceived organizational support, career satisfaction, and performance outcomes: a study of hotel employees in Cameroon. International Journal of Contemporary Hospitality Management 2012, 24, (5), 735752.

64. Guan, X.; Sun, T.; Hou, Y.; Zhao, L.; Luan, Y. Z.; Fan, L. H., The relationship between job performance and perceived organizational support in faculty members at Chinese universities: a questionnaire survey. Bmc Medical Education 2014, 14.

65. Tseng, L.-M.; Yu, T.-W., How can managers promote salespeople's person-job fit? The effects of cooperative learning and perceived organizational support. The Learning Organization 2016, 23, (1), 61-76.

66. Cao, L.; Hirschi, A.; Deller, J., Perceived organizational support and intention to stay in host countries among self-initiated expatriates: the role of career satisfaction and networks. The International Journal of Human Resource Management 2014, 25, (14), 2013-2032.

67. Kim, S., Perceived organizational support as a mediator between distributive justice and sports referees' job satisfaction and career commitment. Annals of Leisure Research 2017, 20, (2), 169-187. 
68. Hofstede, G., Culture's consequences: international differences in work related values. Sage: Thousand Oaks, CA, 2001.

69. Zagenczyk, T. J.; Scott, K. D.; Gibney, R.; Murrell, A. J.; Thatcher, J. B., Social influence and perceived organizational support: A social networks analysis. Journal of Applied Psychology 2014, 99, (3), 450-450.

70. Hayton, J. C.; Carnabuci, G.; Eisenberger, R., With a little help from my colleagues: A social embeddedness approach to perceived organizational support. Journal of Organizational Behavior 2012, 33, (2), 235-249.

71. Chen, Y. P.; Shaffer, M. A., The influences of perceived organizational support and motivation on selfinitiated expatriates' organizational and community embeddedness. Journal of World Business 2017, 52, (2), 197 208.

72. Nilforooshan, P.; Salimi, S., Career adaptability as a mediator between personality and career engagement. Journal of Vocational Behavior 2016, 94, 1-10.

73. Perera, H. N.; Mcllveen, P., Profiles of career adaptivity and their relations with adaptability, adapting, and adaptation. Journal of Vocational Behavior 2017, 98, 70-84.

74. Merino-Tejedor, E.; Hontangas, P. M.; Boada-Grau, J., Career adaptability and its relation to self-regulation, career construction, and academic engagement among Spanish university students. Journal of Vocational Behavior 2016, 93, 92-102.

75. Rudolph, C. W.; Lavigne, K. N.; Zacher, H., Career adaptability: A meta-analysis of relationships with measures of adaptivity, adapting, responses, and adaptation results. Journal of Vocational Behavior 2017, 98, 17-34.

76. Guan, P.; Capezio, A.; Restubog, S. L. D.; Read, S.; Lajom, J. A. L.; Li, M., The role of traditionality in the relationships among parental support, career decision-making self-efficacy and career adaptability. Journal of Vocational Behavior 2016, 94, 114-123.

77. Walen, H. R.; Lachman, M. E., Social support and strain from partner, family, and friends: Costs and benefits for men and women in adulthood. Journal of Social and Personal Relationships 2000, 17, (1), 5-30.

78. Perrin, N. A.; Yragui, N. L.; Hanson, G. C.; Glass, N., Patterns of workplace supervisor support desired by abused women. Journal of Interpersonal Violence 2011, 26, (11), 2264-2284.

79. Thomas, I.; Depasquale, J., Connecting curriculum, capabilities and careers. International Journal of Sustainability in Higher Education 2016, 17, (6), 738-755.

80. Ployhart, R. E.; Vandenberg, R. J., Longitudinal research: The theory, design, and analysis of change. Journal of Management 2010, 36, (1), 94-120. 